\title{
1. The management of intellectual property: introduction
}

\section{Derek Bosworth}

\section{IMPORTANCE OF IP AND IPRS}

The present book brings together 15 chapters by economists, managerial scientists, accountants and lawyers on different dimensions of the management of intellectual property (IP) and, by implication, intellectual property rights (IPRs). Management could, in principle, imply management by government as well as by companies. In practice, the focus of the present contributions is on private sector issues such as the private costs and benefits of alternative strategies, rather than on how the government or international bodies manage (or should manage) IPRs. Almost without exception, the discussion considers company and organizational issues within the context of the existing IPR framework. Thus, the optimal design of the framework of IP laws lies well outside the bounds of the present book.

In principle, IP covers the creative activities of literary, artistic and scientific works; performances of performing artists, phonograms and broadcasts; inventions in all fields of human endeavour; scientific discoveries; industrial designs; trademarks, service marks, and commercial names and designations; protection against unfair competition; and all other rights resulting from intellectual activity in the industrial, scientific, literary or artistic fields (WIPO, 1967, Article 2(viii)).

The present book, in principle at least, has a somewhat broader focus than some of the earlier attempts to explore the management of IP, which have tended to focus on patents and patent-related IPRs (for example, Granstrand, 1999). Patenting remains an important dimension of the present discussion, but there is some coverage of the trade and service marks, as well as an attempt to place them in the broader context of other forms of IP and IPRs. The discussion in this chapter does not dwell on the different forms of IPRs; these are made clear in Chapter 2 (although not every form of IPR is considered) as well as when they are discussed in various other chapters (for example, Chapter 7) In addition the present 
discussion does not outline the distinction between IP, intellectual capital (IC) or intangible assets (IAs), but detailed consideration is given to the differences between them in Chapters 3 to 5 .

\section{THE CHANGING ECONOMIC LANDSCAPE}

The world in which firms operate today is very different to that of the past. While IP and, more broadly, intangible assets have always been important to firms, there is no doubt that the shift towards a knowledge-based economy has given them even greater prominence as a focus for company behaviour and decision-making. This can be illustrated by the growing importance of investment in computers and software vis-à-vis the net capital stock in Australia. The growth in the net information technology (IT) capital stock relative to the overall net capital stock was 4.4 per cent per annum, while the corresponding relative growth in the net stock of software was 6.4 per cent per annum over the period 1991 to 2002 (Figure 1.1). More broadly, Webster $(1999$, p. 58) shows that the ratio of intangible to tangible capital among Australian publicly listed companies approximately doubled over the period 1947 to 1997 (from about 15 to 30 per cent).

By 1997 over half of the value added of the UK was attributed to knowledge-based services and industries (DTI 2001, p. 78). In Germany the

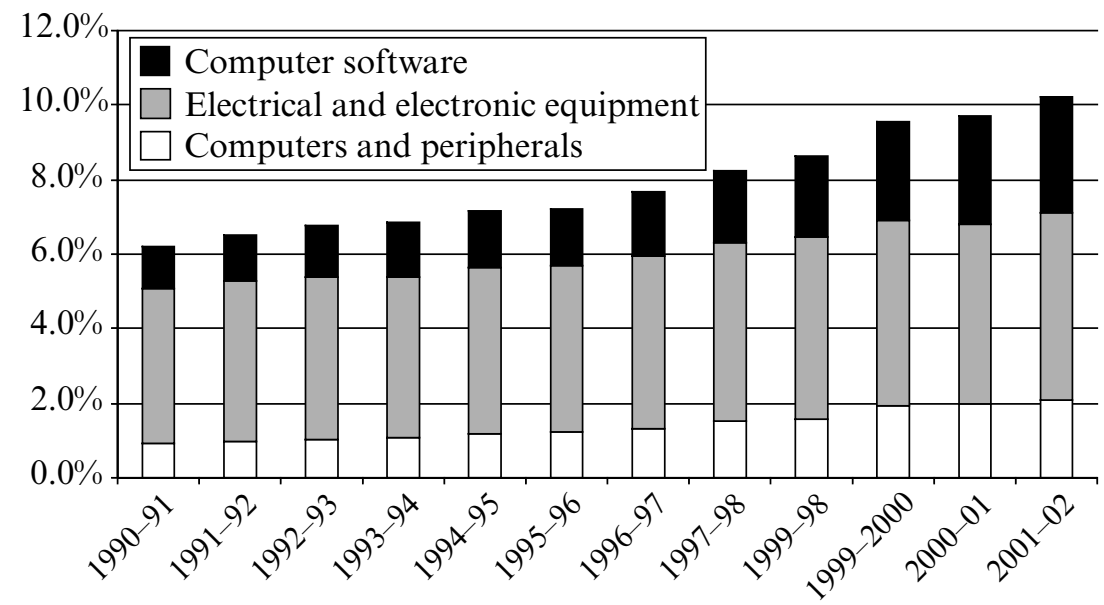

Source: $\quad$ ABS (2004) Cat. No. 5204.0, tables 98 and 86.

Figure 1.1 Share of selected equipment in the net capital stock, Australia, 1991-2002, per cent 
figure was closer to 60 per cent. By late 2004, statistics show that about 11.25 per cent of private sector business investment was on computer software and hardware - about 4.5 per cent on software and 6.75 per cent on hardware. The results of a number of mainly US studies show how such investments have impacted on company organization and performance (see Chapter 5 in this volume; Bosworth, 2005). Estimates of intangibles for particular companies, such as Gillette and Coca-Cola, suggest that they represent significantly higher values than the tangible assets and, even though the ratio of intangible to tangible assets is lower in Proctor and Gamble and Pepsicola, it is still high (Buchan and Davies 1997, p. 116). In the mid1990s GrandMet (now Diageo) reported their brand value to be $£ 3.8$ billion compared with other assets of $£ 7.3$ billion (Corbett 1997); by the year 2000, that value was reported at $£ 5$ billion (Bartram 2000, p. 1).

One reflection of the growing importance of IP and the associated IPRs is the growth in licensing revenues. Ganguli (2000, p. 167) argues that the USA's annual licensing revenue grew from \$200 million in 1980 to $\$ 20$ billion 1997. IBM moved from 1724 registered patents in 1997 to 2658 in 1998 and the company made over $\$ 1$ billion through licensing arrangements. Samsung Electronics, which earned about $\$ 400000$ from its IP in 1998, is reported to be expecting to generate more than $\$ 1$ billion from its Moving Picture Expert Group 2 (MPEG2) technology. High-technology exports are also highly dependent on protection from IPRs. According to the World Development Indicators compiled by the World Bank, high-technology exports formed about 18 per cent of all manufacturing exports in 2003 . However, this overall average hides a huge variation across countries, with the UK having 26 per cent, the USA 31 per cent and East Asia 33 per cent. The percentage for China grew from 17 per cent in 1999 to 27 per cent by 2003.

In this increasingly global economy, many of the changes are linked to IP and IPRs. Foreign direct investment (FDI), for example, often involves various forms of technology transfer, as well as the transfer of management skills, organizational forms, and so on. The World Bank's World Development Indicators database highlights the massive growth in FDI. In the case of China, for example, prior to the open-door policy FDI was largely nonexistent, but this has changed enormously over the subsequent 30 years or so, and by 1999 net inflows of $\mathrm{FDI}^{1}$ had reached US\$38 billion, and by 2003 this had further risen to $\$ 53$ billion. This investment would not have been made without the introduction of a whole raft of IPRs (Bosworth and Yang 2000).

There is considerable evidence that the gestation time between invention and innovation has been falling. Gomulka (1990, p. 37) shows how the average time lag between invention and innovation fell from around 90 years in 1725 to about 20 years in 1925 . He also demonstrates that the 
same patterns of reduction can be found in different areas of technology (for example, basic chemical inventions, basic electronic inventions, other early basic inventions and other modern basic inventions - ibid., p. 36). The finding is not surprising; while there are costs of reducing the applied research cycle time, the benefits can be even larger. In a study of participants in the US Advanced Technology Program (ATP), Laidlaw (2003) asked them to give the economic benefit associated with just a one-year reduction. The estimates ranged from $\$ 1$ million to 'billions' for a one-year reduction (the median was \$5-6 million). These estimates not only exclude the potential broader social benefits, but also the fact that some participants on the ATP believed they had saved up to ten years of research time, saving on expenditure, getting to market early and bringing forward in time the stream of revenues associated with the new product or process.

Products also appear to have moved closer to the science base. In an analysis of the UK Community Innovation Survey 3, Tether and Swann (2003) report that, while a relatively small percentage of all firms utilize the science base as a source of information (19 per cent of production and 14 per cent of service firms), the proportions were significantly higher amongst those that made the greatest commitments to innovation. Half of production and 45 per cent of service firms in the highest quintile of innovators indicated they had used the science base as a source of information for innovation. The result is further confirmed by relating a measure of dynamism among firms undertaking at least some innovation activity and the use of the science base. They report that, while less than one in ten of the firms that scored only one dynamism point used the public science base as a source of information for innovation, more than half those that scored seven or more points used the science base. A similar relationship can be found between innovation expenditures and collaboration with universities and between dynamism and collaboration with universities.

Of course, as the authors point out, there are also indirect ways in which the science base can impact on firms. A simple example is that, while an interaction may lead one firm to be the first to innovate, other firms may imitate this innovation. A further example is that universities supply graduates and there is a link between the employment of graduates and enterprise performance (Bosworth 2005; Bosworth et al. 1992). Tether and Swann (2003) again use the UK Community Innovation Survey to demonstrate this linkage. They report that, within the same industrial subsectors, firms that employ graduates tended to have higher dynamism scores than those that did not employ graduates and, in addition, firms that employ more than the median value of graduates for their sector tended to have even higher dynamism scores. 
Innovation is important in the generation of profit because, even in the presence of patents, firms eventually invent around or invent a superior product or process (Gort and Klepper 1982; Mansfield et al. 1981; Pavitt 1999 ) or the patent eventually expires. When that occurs, abnormal profits created by the innovation are competed away, although some firms may reduce the effects of new competition through their trademarks and brand names. There seems to be a view that product life cycles have become shorter, reducing the period in which monopoly profits are made (Powell 1997; Zirulia 2004, p. 2), although not all authors adhere to this (Bayus 1992; Golder and Tellis 2003). Shorter product life cycles would be consistent with increased innovation activity, the pressure to reduce the applied research cycle time and increased speed to market.

This form of dynamic competition, in which innovation and quality are an integral part, increases the importance of appropriation of the results of discretionary investments of the firm. Discretionary investments refer to expenditures on research and development (R\&D), advertising and marketing, training, management information systems (MIS), and so on. As Laursen and Salter (2005, p. 18) argue, 'Obviously, the ability of innovative firms to control the imitation strategies of other firms in their market will always remain limited. However, the choices managers make about how best to protect their intellectual capital can be a matter of life and death for their firm'.

Laursen and Salter (2005, pp. 19-20) outline the two major contrasting strategies for appropriation: a 'legal strategy' and a 'fast mover strategy'. They conclude that,

Both legal and fast mover appropriability strategies, associated with increased managerial attention to appropriability, helps innovative performance. This finding indicates that managerial researchers are right to point to the need for managers to greater attention to appropriation in the development of their corporate and innovation strategies. However, we also found that an overemphasis on either legal or fast mover appropriability can have detrimental consequences for innovation performance - this is especially the case with respect to the legal appropriability strategy.

One other feature is that these forms of investment, which have become increasingly important with the passage of time, are inherently risky - a factor which management (and shareholders) have to take into account. New forms of decision-making focusing on the inherent risk or uncertainty need to be introduced.

As IP and other intangibles have taken centre stage, IPRs have become a strategic policy issue both at the company level and nationally. The USA has been at the forefront of changing the IPR landscape initially at least through 
what became known as 'Special 301', introduced under the Omnibus Trade and Competitiveness Act, signed by President Reagan in 1988. Section 301 authorizes the US Trade Representatives (USTR) to retaliate against countries that take unjustifiable, unreasonable or discriminatory trade practices. The USA was also actively involved in the Uruguay Round of the General Agreement on Tariffs and Trade (GATT), which set out the agreement on Trade-Related Aspects of Intellectual Property Rights (TRIPS) in December 1993 and established the World Trade Organization (WTO), both of which became effective in 1994. This was an attempt to overcome the wholly inadequate protection for IP in many developing countries. TRIPS is binding on all WTO signatories and, hence, formed a further source of pressure for countries such as China, who wanted to become a WTO member, to introduce the necessary IP legislation. Under TRIPS, any countries intent on accessing world markets must introduce and enforce IP protection of the same standard as developed countries within five years. At the same time a range of parallel negotiations at the international, regional and bilateral levels has been taking place, which has already begun to reshape the existing IPR regime - the so-called 'TRIPSplus' agreements (Vivas-Eugui, 2003). These agreements often involve commitments well beyond the minimum standards set by TRIPS.

\section{THE FOCUS AND CONTENTS OF THE PRESENT BOOK}

The developments outlined above have major implications for the management of companies. The present book focuses on information and analytical tools used for the management of IP and intangible assets. These assets are driven by investments in $\mathrm{R} \& \mathrm{D}$, advertising and marketing, education and training, management information systems, organizational structure, and so on. The development of such assets can involve invention or some other creative step, as well as innovation. The investments and the activities involved are all inherently risky. Thus, understanding the management of IP and intangible assets requires inputs from a variety of disciplines, including economics, law, accounting and finance, management, and so on.

Part II of the book contains four chapters drawn from four different disciplines, providing legal, accounting, management and economic perspectives. These chapters describe how the different disciplines define and view intellectual property and other intangible assets, as well as describing the evolution of the literature in their area. 
Chapter 2, by Andrew Christie, gives a legal perspective. It indicates how the importance of and interest in IP and IPRs has grown over time, and how a knowledge gap has emerged among certain sections of the community as the range of rights has increased and the overall framework of protection has become more complex. The discussion suggests that this area is made complicated by the fact that IP laws create rights between individuals that are vested in intangible 'objects'. The chapter begins with an outline of four somewhat different interpretations of what the law means by intellectual property. It points out that the subject matter of IP is generally derived from various forms of human intellectual - generally creative - activities. Property is taken to mean the legal rights to the subject matter, rather than the subject matter per se and the subsequent discussion outlines a particular case which illustrates this point. Intangible assets, such as IP have the problem that they cannot be physically secured to prevent their use by third parties. While IPRs offer a certain degree of exclusivity of rights over certain creative outputs, the chapter argues that these are not absolute in nature for a variety of reasons. The chapter then goes on to outline the principle regimes governing IP law - copyright, designs, patents and trademarks - as well as other statutory regimes, such as integrated circuits and plant breeders rights, and briefly touches on non-statutory regimes such as trade secrets.

In Chapter 3, Anne Wyatt sets out the issues surrounding IP and IPRs from an accounting perspective. Although intangible assets have no physical form, they are nevertheless viewed as potential sources of long-term future economic benefit. As in the case of the legal perspective, the 'asset' is formed by the right that the owner - the firm - has to control access to and use of the asset. For any item to appear in the accounts, it has to meet both the recognition and definition rules, which are set out in detail. The asset can only be recognized and appear on the balance sheet if it gives rise to probable future economic benefits and if it has a cost or some other value that can be reliably measured. Given that there is considerable uncertainty over both the future value of many of these assets, as well has how to place a value upon them, this provides a major restriction over what accountants can or are allowed to do in their accounts.

Despite the obvious evidence of the increasing importance of intangible assets within companies, advances in accounting standards to reflect them are reported to be scant. Practices such as expensing internal investments in $R \& D$ appear to be the norm. Wyatt reports that, if anything, the trends in accounting standards have been away from the recognition of intangible assets, while economists and most management scientists have been arguing for just the opposite. This does not mean that companies are not recording intangibles outside the formal financial and accounting activities-for use 
by managers in the effective management of the company. However, Wyatt argues that, to the extent the externally reported data drives the internal data collection, internal (management) and external users of accounting information will not have accurate data for their investment decisions.

In Chapter 4, Laurie Hunter provides a management perspective on IP and, indeed, the broader range of intangible capital within which IP is embedded. Intangible capital comprises human capital, organizational capital, relational capital and IP. Again the discussion outlines the various trends that have enhanced the importance of intangible assets and placed them centre stage as a vital factor in competitive rivalry in many sectors of business. It is the ownership of the rights over such assets that provide a potential form of competitive advantage, for example, the ability to preclude other companies from producing a particular product or using a particular technology. The management view is that IP is complex, as it involves elements of the firm's know-how and competencies, as well as the products of other creative activities, such as R\&D, carried out by the company.

As such activities are core to competitiveness, it is argued that there is a real concern over the current failure of the accounting profession to address the measurement issues, although an understanding of the problems they face. It is crucial for managers taking strategic decisions of the firm to understand what intangible investments will pay off in the future and how well they will pay off. This requires at least internal measurement and accounting, even if this is not externally reported. However, Hunter suggests that all too often internal reporting systems are developed simply to supply the formal financial and accounting activities. The final part of the chapter is devoted to the idea of developing some system or framework of internal metrics and indicators that will be of use to management decision-making.

Derek Bosworth and Beth Webster, in Chapter 5, provide an economic perspective of a number of the issues surrounding the management of IP. While Chapter 4 outlined the main components of intangible capital including IP, Chapter 5 begins with a discussion of the nature of intellectual capital and how this can be distinguished from the broader concept of intangible assets. It not only reconsiders the question of ownership rights, but introduces the concept of appropriability - the ability to appropriate the rewards from the ownership of the IP that allow the creator to recoup the investment expenditures made in developing the creation. In addition, the chapter outlines the special nature and properties of intangible assets from an economic perspective - not just that intangibles do not have a physical form, but that their contribution to the profitability of the firm is often associated with uncertainty or, at best, a high degree of risk. There are many sources of risk and uncertainty, for example, they attach to investments in $\mathrm{R} \& \mathrm{D}$ and the ability to appropriate the rewards from such investments (for 
example, obtaining a defensible patent). Certain types of intangible assets such as knowledge, have other special properties, such as indivisibility.

The chapter then turns to the internal discretionary investments of the enterprise in IAs from an economic perspective (that is, expenditures on $\mathrm{R} \& \mathrm{D}$, advertising, training, and so on). In particular, it considers the economic evidence about the degree to which the ex ante investment decisions focus on the likely effects on the profitability of the enterprise. In doing so, the discussion outlines the role played by both science- and technologypush factors vis-à-vis demand-pull factors. While historically these were seen as alternative explanations of the rate and direction of technological change, today they are generally integrated in an eclectic empirical model. Having dealt with the internal investments, the chapter then explores the sources of IAs that lie external to the firm and how the enterprise might efficiently access such sources. It is argued that efficient access to external sources generally require internal discretionary investments of the type outlined above. Finally, Chapter 5 looks at studies of the value of IAs to enterprises. In doing so, it extends the discussion beyond the traditional focus on R\&D and explores other investments, such as high-performance work practices (HPWPs) and IT.

Part III considers the issue of the linkages between IP and company performance, and the issue of using IP-based measures to monitor and benchmark performance. All of these in some way draw upon the market valuation approach developed by Griliches (1981). In this approach, market valuation represents the expected discounted sum of future dividends, which, if the retention ratio - the proportion of profits paid as dividend - remains reasonably constant, will be directly related to the expected sum of discounted future profits (see Chapter 5). All the studies in this part use 'panel data', which combines cross-sectional and time-series data about individual companies. Panel estimation techniques allow the researcher to control for unmeasured company characteristics that do not vary over time. As Griffiths and Webster (Chapter 8) point out, 'This may include that part of the expertise of a specific manager, a particular customer market advantage a firm possesses which is constant over the data period'. Or, as Jensen and Palangkaraya suggest (Chapter 9), it may be able to capture unobserved influences on performance, such as the possession of trade secrets.

Dirk Czarnitzki, Bronwyn Hall and Raffaele Oriani, in Chapter 6, outline their preference for market valuation as the performance measure rather than current profits, which fail to represent the stream of benefits than an innovation is likely to bring. The authors present an outline of what they term a 'hedonic regression approach to measuring the market value of the knowledge assets'. By this they mean that they specify a relationship 
in which various tangible and intangible assets influence the performance and, hence, the market value of the company. The term 'hedonic' refers to a literature linking product prices with their characteristics or attributes - in the present case the 'product' is the company. With one or two variations, this approach is widely adopted in the literature and underpins all the chapters in this part of the book.

Given that the chapter draws upon a wide range of estimates, including those undertaken by the authors themselves, the discussion outlines the way in which the generally used measures are constructed. For example, the study outlines the construction of an 'R\&D stock of knowledge', using the perpetual inventory method (for example, the depreciated sum of past R\&D expenditures, where the depreciation rate is assumed to be 15 per cent), as well as the relationship between the R\&D stock and flow measures. Problems with the R\&D measures as a proxy for knowledge capital are also discussed. As the authors point out, many studies also use patent data in an attempt to partially overcome any measurement problems associated with R\&D. The patent data take the form of either simple patent application counts or citation-weighted patent counts. The rationale for the citation weights is that patents which are more heavily cited by subsequent patents are likely to be technologically and commercially more important. Past results from applying the method to firm data on market value, capital, R\&D and patents are summarized, along with a more detailed presentation of some recent results for US and European firms. The conclusion is that measures based on $\mathrm{R} \& \mathrm{D}$, patents and citation-weighted patents are each highly significant in a market value regression, although patent-based measures tend to be somewhat less significant in the presence of R\&D measures.

Chapter 7 by Christine Greenhalgh and Mark Rogers makes an important contribution in two respects: first, it extends the IP data from just patents to include trademarks; second, it provides an analysis of the financial services sector, the transport, communications and utilities service sector, and manufacturing. They use firm-level data on the intellectual property activity of around $1300 \mathrm{UK}$ companies, to analyse the importance of trademarking and patenting over the period 1996 to 2000 . The authors note that patenting activity is minimal in the two service sectors, but trademark activity is substantial across all three sectors. All sectors experienced an increase in IP activity over the period, although the most rapid growth is in trademarking by financial service sector firms. In addition, the database contains financial information, allowing the construction of a measure of market value.

The authors present some descriptive statistics that compare four different performance measures for trademark active and inactive firms. In virtually all cases trademark active firms outperform inactive firms. They also report 
results which show a very similar pattern emerges for patent active and inactive. The authors then set out a fairly standard economic model for the analysis of the relationship between the net present value of the firm, as reflected in its market value, and the tangible and intangible assets of the firm, including within the latter its IP. Their results show important differences across sectors. For manufacturing firms, UK and European Patent Office (EPO) patent activity is associated with higher stock market values, with trademarking having little impact. In contrast, for financial sector firms, higher trademark intensity is associated with higher market values. Furthermore, for financial sector firms, the market's valuation of trademarking increased in the late 1990s.

Chapter 8 , by Bill Griffiths and Beth Webster, also uses a market value framework to examine the relationship between the effort Australian companies make creating assets and future anticipated profits. The focus of their study is not so much the value of innovative activities, but the extent to which the value has been rising or falling over time. In doing so, the study adopts a long panel data set, comprising over 300 Australian companies from 1989 to 2002. While they adopt similar measures to the previous authors, there are a number of differences. The Australia data provided by IP Australia include design information as well as patents and trademarks. In addition, there is information about whether the patents, trademarks and designs are still in force, which provides accurate figures about the stocks of IP, rather than having to estimate them with assumed depreciation rates.

In their initial model, they obtain estimates of the value of each type of IP, where on average: the value of an additional patent (with other unmeasured and correlated investments) adds A\$933000 to the value of the company; an additional trademark adds A\$141000; and an additional design adds $\mathrm{A} \$ 803000$. The authors then allowed the values of each form of IP to vary linearly over time. Their main findings were that: the average present value of a patent fell from 1989 to 2002, which they tentatively suggest might be attributed to the lower intrinsic value of invention over time or more competitive markets; the average present value of a registered trademark rose, which they suggest may be due to strong macroeconomic growth over that period, the rising importance of branded goods and services and/or the benefits to firms of using brands as barriers between themselves and rivals.

In Chapter 9, Paul Jensen and Alfons Palangkaraya report on the construction of an index of innovative activity at the company level for Australian companies. The innovation index is based on the same market valuation approach described in the earlier chapters and reflects many of the recent developments in the academic literature. The authors reject the 
use of a single indicator of innovation, such as $R \& D$ expenditure, patent counts or the number of new products introduced over any given period of time. They argue that multiple indicators give the researcher a much better chance of establishing the true extent of company innovativeness and adopt a market valuation function that includes $R \& D$, patents, trademarks and designs. Each of the indicators relates to a different stage of the innovation pathway, as, for example, $R \& D$ relates to a measure of inputs to the innovation process, patents reflect that an invention has been made and trademarks are often taken out at the stage that a modified or new product has been launched.

The market valuation equation is estimated to provide weights for the various indices of innovation. The weighted sum of the indicators then forms an index, which is then used to compile an 'innovation scoreboard'. The data, provided by IBISWorld and IP Australia, are restricted to those companies for which both R\&D and market value information are available. The weighted sum of the R\&D and IP indicators gives each firm's indexed 'score' in a given year, which forms the basis of the authors' comparison of the innovative performance of Australian companies and sectors over the period 1998-2003. Matching their data to a survey of Australian companies, the authors are able to explore what factors distinguish the most innovative companies from the rest. They report that the most innovative companies are more likely to pursue information gathering from primary sources (for example, their clients) and do so in a more systematic way. The innovative firms more readily adapt their strategic plans to meet the challenge of external changes and are more likely to develop new products and react to early signs of opportunity in the market.

Part IV considers a number of strategic management issues, including the decision to take out formal IP protection and the more general management of intangible assets. Chapter 10 focuses on an overview of the benefits of a company focus on IPRs; Chapter 11 looks at the propensity to trademark, as well as the links between trademarking and company performance; and Chapter 12 examines the propensity to patent and the determinants of the size of the patent portfolio.

While chapters in the previous part of the book were based on the analysis of large-scale statistical databases, showing the link between IP and company performance, in Chapter 10, Derek Bosworth draws upon information built up during case studies of IP and IPRs by the author and illustrates them with examples drawn from other sources, such as the World Intellectual Property Organization (WIPO) small and mediumsize enterprises (SME) case study website. This allows a richer picture to emerge as to how IP and IPRs are managed in order to lever value to the companies that own them. In particular, the chapter discusses the value of 
the technical information reported in patent specifications as a source of technical information that firms can use in their own creative activities. It demonstrates how patenting can be used as strategic activity to hinder other companies' inventive activities. Finally, it reports on examples of where companies use their patents as a 'shop window' to attract potential clients. The discussion then turns to the use of patent (and other IPR) watching and search mechanisms for discovering what rivals, potential takeover targets and potential collaborators are doing.

Chapter 10 then looks at the use of patenting as a mechanism for triggering rewards to motivate and incentivize employees. It considers the role that IPRs play not only in attracting investors, but also as collateral for raising funding. Issues concerning the raising of finance may be particularly important in increasingly knowledge-based firms with few tangible assets that can be used as surety. The discussion then turns to the role of IPRs in allowing various forms of licensing and franchising, for example, the role of patents in allowing the licensing of a firm's technology. The author then moves on to consider the use of cross-licensing and patent pooling to improve the firm's freedom to operate and to increase access to technologies owned by other companies. At this stage it is possible to show how IP and IPRs can act as a key strategic focus of the enterprise, as well as how different IP and IPR strategies become increasingly woven into the business strategy of the firm. Finally, the chapter concludes with a discussion of the more traditional role of IPRs in protecting the firm against infringement, thereby enabling it to recoup its R\&D and marketing outlays and improve its dynamic performance.

In Chapter 11 Christine Greenhalgh and Mark Rogers document the extent of intellectual property assets held by financial services firms, which they then compare with corresponding intangible assets held by manufacturing firms and utilities providers. In practice, financial services is a very important sector in the UK, for example, in terms of employment; it accounts for about 16 per cent of total employment, compared with 14 per cent in manufacturing. They argue that the financial services sector now plays a role that was previously carried out by manufacturing, both as an engine of productivity growth and a transmitter of innovation. Growth through innovation was associated with service product differentiation and a rapid increase in product range, which is likely to be reflected in trade- and service mark activity. Thus, the authors focus on the extent and determinants of trademark activity and whether this activity is linked to firm performance.

Greenhalgh and Rogers demonstrate that the strong growth and development of the financial services sector in the UK has been accompanied by a significant rise in the acquisition of intangible assets in the form of intellectual property rights held by firms in this sector. The main type of IP 
asset acquired was trademarks, with only a few venture capital companies reporting R\&D expenditure or acquiring patents. This pattern is consistent with the development of new varieties of financial services products, using new process technology bought-in from the manufacturing sector. Even so, the incidence of new trademarks during 1996-2000 for financial service firms was still zero in over half these firms; this is well below the rates in the manufacturing and utilities sectors. Although large firms account for much of the observed trademark activity, smaller firms make more trademark applications per employee. They found no role for stock market listed status or the extent of product diversification of the firm in the propensity to acquire trademarks. Across all firms a variety of measures of firm performance were positively correlated with being active in acquiring trademarks; within the financial services sector, trademark active firms showed higher rates of investment and faster growth of employment.

In Chapter 12, Carine Peeters and Bruno van Pottelsberghe de la Potterie attempt to gain a better understanding of large firms' patenting behaviour. The conceptual framework suggests that this behaviour can be influenced by three types of factors: (1) the innovation strategy and the general attitude of firms towards IPRs; (2) the barriers firms perceive as hindering their innovation activities and as preventing them from patenting; and (3) firmand sector-specific factors like size, age and the level of competition. The authors undertake a quantitative analysis of the effect of these factors on the propensity to patent and the number of patents held. Two econometric models are estimated using an original survey of 148 large Belgian firms in 2001. Firms are categorized by size (small, medium and large) and by sector (high, medium and low technology, plus services). The rich database contains a variety of new measures, distinguishing, for example, basic and applied R\&D from development activities.

Both the probability of having a patent portfolio and the size of this portfolio correlate with four dimensions of an innovation strategy: a focus on basic and applied research (as opposed to development); the effective collaboration with knowledge-based institutions (university and public labs) or with competitors; a product-orientated strategy (as opposed to process); and the importance given to a formal management of intellectual property. The firms that perceive more barriers to their innovation process (internal organizational barriers, risk- and cost-related barriers, and external barriers coming from customers' rigidities and inappropriate regulations) patent less than other firms. The perception of barriers to the use of the patent system is not correlated with the actual patenting behaviour.

Part V turns attention to the specific decision rules to be used when taking decisions under risk. All stages of the innovation processes generally associated with IP are inherently risky, from the investment in basic research, 
applied research, development, seeking patent or trademark protection, product launch and competitor response, to patent renewal or lapse. While these stages should not be conceived as wholly linear, there are key times at which decisions have to be made and each choice has a degree of risk or uncertainty. These choices depend upon the adoption of appropriate valuation techniques.

Chapter 13, by Eric Iversen and Aris Kaloudis, argues that more reliable valuation techniques can lay the basis for better management of innovation processes within the firm, as well as allowing better co-ordination mechanisms between innovating firms and the wider economy (for example, collaborators, funding agencies, users, and so on). The authors describe three basic scenarios that help substantiate the increasing relevance of valuation techniques, and the challenges they pose. The first involves the changing way innovation activities are organized, such as collaborative research, which requires an agreed way to value IAs prior to, during and after the collaboration. This second scenario is where there are high $R \& D$ costs and long gestation periods, where valuation techniques are needed in order to obtain investment. A third scenario emerges at the firm-level, in cases where the challenge of proactively organizing company activities substantially involves IAs. Thus, the authors argue that, to be successful, a firm must know the value of its IAs, have a strategy for monetizing them, and be effective in generating a return on them. They go on to outline how improved valuation techniques would also improve the macroeconomy.

Iversen and Kaloudis reiterate the importance of distinguishing between the value of the invention and the value of the patent protection. They then introduce a variety of different cost-based and value-based approaches to the valuation of intangible assets, including real option methods which they view as the potentially most promising way forward. In addition, they outline the use of balanced scorecards and citation analyses. From an empirical perspective, the authors present interesting evidence about Norwegian companies' patenting activities. This shows significant differences in the completion of the patenting process: individual inventors and small firms are much more likely to withdraw their application before it is granted. Higher withdrawal rates may be an indication of the lower quality of the invention, poor framing of the application, fear of litigation, and so on. However, it may also reflect an inability to value the invention and demonstrate this value to potential funding agencies and other organizations that might help in the development and commercialization of the invention. The authors argue for the need to improve firm-internal processes, including knowledge of valuation techniques.

In Chapter 14, Robert Pitkethly makes the case for the objective valuation of patents. He argues that the inventor, the patent agent and marketing 
managers are likely to be the individuals with the information and knowledge to allow this to take place. The author notes that companies all too often do not consider carrying out an objective valuation of patents, which are then applied for or renewed because no one can or wants to prove that they are not valuable. In addition, it is important to distinguish between the patent, the underlying invention and commercialization of the patented invention in decisions such as whether to apply for a patent or to renew a patent.

The discussion then turns to a description of the various methods of valuation. These include: (1) cost- and market-based methods - accounting for historical costs and market conditions; (2) income-based methods accounting for future value; (3) discounted cash flow methods - accounting for time and uncertainty; (4) decision tree analysis methods - accounting for flexibility; (5) options pricing theory methods - accounting for changing risk. All these methods are discussed, although Pitkethly concentrates on those that he feels are more accurate and useful. The author argues that option-based valuation approaches are a useful framework within which to consider management decisions about company IPRs even if the method is not applied in detail. He suggests that valuation methods for assets involving choices and varied outcomes can seriously understate their true value if they do not take account of any options involved. In addition, an important part of the discussion of a number of the above techniques is that investments are often multi-stage in nature and the degree of risk differs considerably across these stages. In order to operationalize the options pricing approach, information is needed about the distribution of returns. Here Pitkethly points to the emerging, mainly econometric literature on the skewed distribution of returns, which suggests that a search for meaningful distributions is worthwhile.

In Chapter 15, Markus Reitzig seeks to complement Pitkethly's (1999) survey of patent valuation methods (see Chapter 14, which contains much of the earlier paper). The identification of spanning traded assets, used to provide estimates of the present value of the cash flows and their volatility for the options pricing calculation, are difficult to identify in the case of patents and, more particularly, patent portfolios. For this reason, the author attempts to assess patent value without market benchmarking, by searching for patent-based indicators that are likely to be strongly correlated with patent value and can act as proxies for the cash flows and their volatility. The author argues that, in addition to their correlation with 'value drivers', such indicators should be both publicly available and able to provide lowcost valuations.

The types of value drivers that Reitzig has in mind are (1) the patent's duration (or remaining life time), which corresponds to the maximum time to invest in the project; (2) the present value of cash flows which 
will be related to its novelty, inventive step (non-obviousness), disclosure, breadth, difficulty in inventing around, its position within a portfolio of other patents and the complementary assets of the patent holder; (3) the standard deviation of the patent's value (volatility) is likely to be determined by technical, legal and market uncertainty. The author then undertakes a review of the empirical literature linking the potential indicators with the value of patents. The chapter also discusses the shortcomings of current practice, including the problem of assigning weights to indicators and assigning indicators to the input parameters of a real option valuation. While the latter would be ideal, if done correctly, Reitzig argues that we are still some way from being able to do so. Nevertheless, he argues that more simplistic valuations using indicators are still worthwhile, particularly where large portfolios of patents need to be evaluated quickly and on a regular basis.

\section{NOTE}

1. The World Bank defines this as net inflows of investment to acquire a lasting management interest (10 per cent or more of voting stock) in an enterprise operating in an economy other than that of the investor. It is the sum of equity capital, reinvestment of earnings, other long-term capital and short-term capital as shown in the balance of payments. This series shows net inflows in the reporting economy. Data are in current US dollars.

\section{REFERENCES}

Bartram, P. (2000), 'Brand power', Management Accounting, June, 17-18.

Bayus, B.L. (1992), 'Have diffusion rates been accelerating over time?', Marketing Letters, 3, 215-26.

Bosworth, D.L. (2005), Determinants of Enterprise Performance, Manchester and New York: Manchester University Press.

Bosworth, D.L. and D. Yang (2000), 'Intellectual property law, technology flow and licensing opportunities in the People's Republic of China', International Business Review, 9 (4), 453-77.

Bosworth, D.L., R. Wilson and P. Taylor (1992), Technological Change: The Role of Scientists and Engineers, Aldershot: Avebury Press.

Buchan, E. and N. Davies (1997), 'Mergers and acquisitions', in R. Perrier (ed.), Brand Valuation, London: Premier Books, pp. 109-16.

Convention Establishing the World Intellectual Property Organisation (1967), article 2 (viii), http://www.wipo.int/treaties/en/convention/trtdocs_wo029.html.

Corbett, G. (1997), 'The benefits of valuing brands', in R. Perrier (ed.), Brand Valuation, London: Premier Books, pp. 11-18.

Department of Trade and Industry (DTI) (2001), UK Productivity Competitiveness Indicators, London: Department of Trade and Industry.

Ganguli, P. (2000), World Patent Information, 22, 167-75. 
Golder, P.N. and G.J. Tellis (2003), 'Growing, growing, gone: cascades, diffusion, and turning points in the product life cycle', report no. 03-120, Marketing Science Institute, Cambridge, MA.

Gomulka, S. (1990), The Theory of Technological Change and Economic Growth, London: Routledge.

Gort, M. and S. Klepper (1982), 'Time paths in the diffusion of product innovations', Economic Journal, 92 (367), 630-53.

Granstrand, O. (1999), The Economics and Management of Intellectual Property, Cheltenham, UK and Northampton, MA, USA: Edward Elgar.

Griliches, Z. (1981), 'Market value, R \& D, and patents', Economic Letters, 7, 183-7.

Laidlaw, F.J. (2003), 'Acceleration of technology development by the Advanced Technology Program: the experience of 28 projects funded in 1991', US Office of Economic Assessment, National Institute of Standards and Technology, Technology Administration, US Department of Commerce, www.atp.nist.gov/ eao/ir-6047.htm\#Chapter\%201.

Laursen, K. and A. Salter (2005), 'My precious: the role of appropriability strategies in shaping innovative performance', Danish Research Unit for Industrial Dynamics, working paper no. 05-02, Copenhagen Business School. Frederiksberg, Denmark.

Mansfield, E., M. Schwartz and S. Wagner (1981), 'Imitation costs and patents: an empirical study', Economic Journal, 91, December, 907-18.

Pavitt, K. (1999), Technology, Management and Systems of Innovation, Cheltenham, UK and Northampton, MA, USA: Edward Elgar.

Pithelky, R. (1999), 'The valuation of patents: a review of patent valuation methods with consideration of option based methods and the potential for further research', Judge Institute working paper WP 21/97, Cambridge.

Powell, J. (1997), 'Development, commercialization, and diffusion of enabling technologies: progress report for projects funded 1993-1995', Office of Economic Assessment, Advanced Technology Program, National Institute of Standards and Technology, report NISTIR-6098, US Department of Commerce Gaithersburg, www.atp.nist.gov/eao/ir-6098/contents.htm.

Tether, B.S. and G.M.P. Swann (2003), 'Sourcing science: the use by industry of the science base for innovation; evidence from the UK's Innovation Survey', discussion paper, Centre for Research into Innovation and Competitiveness (CRIC), University of Manchester and UMIST.

Vivas-Eugui, D. (2003), Regional and Bilateral Agreements and a TRIPS-plus World: The Free Trade Area of the Americas (FTAA), Quaker United Nations Office (QUNO), Geneva; Quaker International Affairs Programme (QIAP), Ottawa; International Centre for Trade and Sustainable Development (ICTSD), Geneva.

Webster, E. (1999), The Economics of Intangible Assets, Cheltenham, UK and Northampton, MA, USA: Edward Elgar.

WIPO (1967), Convention Establishing the World Intellectual Property Organization. Zirulia, L. (2004), 'The evolution of R\&D networks', MERIT-Infonomics Research Memorandum series, working paper 2004-007, Merit, Maastricht. 